\title{
Modifying the Details of Aspiration Operation may Contribute to the Improvement of Prognosis of Patients with ICH
}

\author{
Intrakraniyal Kanaması Olan Hastalarda Aspirasyon İsleminin Değişik \\ Bir Uygulamasinin Detaylarn
}

\author{
Zhou-Ping TANG ${ }^{1}$, Yuan-Hong SHI ${ }^{1,2}$, Xiao-Ping YIN ${ }^{3}$, Jin-Zhi XU ${ }^{1}$, Su-Ming ZHANG ${ }^{1}$, Wei WANG ${ }^{1}$ \\ ${ }^{1}$ Tongji Hospital, Tongji Medical College, Huazhong University of Science and Technology, Department of Neurology, 1095, Jie-Fang Road \\ Wuban, 430030 China \\ ${ }^{2}$ Subei Hospital, Affiliated Hospital of Yangzhou University, Department of Neurology, China \\ ${ }^{3}$ Affiliated Hospitals of Jiujiang University, Department of Neurology, China
}

This study was supported by National Natural Science Foundation of China (30770751) and Scientific Research Foundation of Health Department of Hubei Province (JX4A03).

Correspondence address: Wang WEI / E-mail: ddjtzp@163.com

\begin{abstract}
AIM: The aim of the retrospective study was to compare the clinical efficacy of the traditional way of aspiration and the modified way of aspiration.

MATERIAL and METHODS: Clinical data of total 159 patients with spontaneous intracerebral hemorrhage treated by traditional (group A, $\mathrm{n}=66$ ) or modified (group $\mathrm{B}, \mathrm{n}=93$ ) way of aspiration (both combined with thrombolysis) were retrospectively analyzed. Reduction of clot volume in the first operation, rate of mortality and re-bleeding, complications, and long-term clinical outcomes of the two groups were compared.

RESULTS: Twenty-five out of 159 patients (15.7\%) died during in-hospital stay. The mortality and post-operation re-bleeding rate in group B $(10.8 \%$ and $1.1 \%)$ were significantly lower than that in group $A(22.7 \%$ and $9.1 \%),(P<0.05)$. The $B I$ scores of patients in group $B(79.5 \pm 23.2)$ were significantly higher than that in group $\mathrm{A}(69.2 \pm 23.9),(\mathrm{P}<0.05)$.
\end{abstract}

CONCLUSION: Our data suggested that modifying details of aspiration operation may contribute to the improved prognosis of ICH patients. KEYWORDS: Hematoma aspiration, Thrombolysis, Intracerebral hemorrhage, Outcome

öz

AMAÇ: Retrospektif olarak yapılan bu çalışmada, klasik yol ile yapılan aspirasyon (Grup A) ile değiştirilmiş (modified) (Grup B) yöntemle yapılan aspirasyonun klinik etkinliği karşılaştırılmıştır.

YÖNTEM ve GEREÇ: Spontan intrakraniyal kanama geçiren 159 hasta retrospektif olarak iki ayrı grup halinde incelendi. İlk gruptaki 66 hastaya geleneksel yoldan aspirasyon yapılırken, 2. gruptaki 93 hastaya tromboliz yapılarak aspirasyon uygulanmıştır. Pıhtı hacmindeki azalma, mortalite hızı, yeniden kanama, komplikasyonlar ve geç dönem klinik sonuçları iki grupta karşılaştırılmıştır.

BULGULAR: Toplam 159 hastadan, 25'i hastanede kaldıkları sürede öldü $(\% 5,7)$. Mortalite hızı ve yeniden kanama hızı grup B'de (\%10,8 ve $\% 1,1$ grup A'ya $(\% 22,7$ ve $\% 9,1)$ göre anlamlı şekilde düşük olarak bulundu $(P<0,05)$. BI ölçütlemesi grup B'deki hastalarda $(79,5 \pm 23,2)$, grup A'daki $(69,2 \pm 23,9)$ hastalara göre anlamlı şekilde daha yüksek bulundu $(P<0,05)$.

SONUÇ: İntrakraniyal kanaması olan hastalarda modifiye edilmiş aspirasyon yöntemi ile prognoz daha iyi hale gelebilmektedir.

ANAHTAR SÖZCÜKLER: Hematom aspirasyonu, Trombolizis, İntrakraniyal kanama, Sonuç

\section{INTRODUCTION}

Intracerebral hemorrhage (ICH) has a high mortality (35\%$52 \%$ at he 30 th day) and only about $20 \%$ of survivors achieve a favorable functional outcome $(1,3,23)$. Surgical removal of hematoma helps to relieve the mass effect of hematoma and to prevent the secondary damage induced by toxic substances precipitated from hematoma $(16,17,21,25)$. However, the clinical effectiveness of this treatment way was still controversial $(11,12,18)$. Despite still being a matter of debate, the treatment of spontaneous ICH by thrombolytic therapy and aspiration of clots has gained wide acceptance. The prominent advantages of this treatment method are (a) less damage to the normal regions of brain; (b) local 
anesthesia; (c) high efficiency of removing hematoma (4, 9, $15,24)$.

At the end of 1990's, the surgical technique of aspiration with metal puncture needle combined with thrombolysis of $\mathrm{ICH}$ was promoted by Ministry of Health of China and was quickly accepted by most hospitals. Till the beginning of 2008, more than 400 thousand patients had received this operation according to a report from the $5^{\text {th }}$ national symposium on aspiration with metal puncture needle of hematoma in mainland of China (11/28/08 to 12/02/08, Kunming, China). In China mainland, a large number of reports had suggested that this treatment way helped to reduce the mortality and complications and to improve the long-term quality of life of survivors $(26,27,28)$. However, more convincing evidences are still needed.

We adopted this technique at 2000, and till now the total number of patients whom had received this operation had reached at 200. In practice we realized that some details of operation should be modified (i.e. not to pay too much emphasis on hematoma reduction in the first operation) to reduce the mortality and re-bleeding rate and to improve the long-term clinical outcome.

The aim of the retrospective study was to compare the clinical efficacy of the two ways of aspiration (traditional and modified aspiration) in 159 patients.

\section{MATERIAL and METHODS}

\section{Subject Population}

Patients with spontaneous $\mathrm{ICH}$ treated by aspiration with a metal puncture needle (the $\mathrm{YL}-1$ type of puncture needle, Beijing WanTeFu Medical Apparatus Co., Ltd) and subsequent thrombolysis therapy for hematoma were enrolled in the trial. In our hospital, between December 2000 and October 2004 , patients were treated by traditional way of aspiration and since November 2004 patients were treated by modified way of aspiration. All the surgical procedures were performed by the same two neurologists. Inclusion criteria were as follows: CT diagnosis of spontaneous supratentorial $\mathrm{ICH}$ (deep lobar, basal ganglia or thalamus), hematoma volume $\geq 30 \mathrm{~cm}^{3}$ (according to the criteria of China guideline for cerebrovascular disease prevention and treatment), having neurological signs, clinical onset $<72 \mathrm{~h}$ before intervention (in accordance with the criteria adopted by most authors), aged 18 to 80 -year-old, follow-up duration $\geq 3$ months. Exclusion criteria were as follows: clotting mechanisms obstacles, signs of transtentorial herniation $>2 \mathrm{~h}$, severe concurrent illness, having neurological deficits before onset, affirmative structural etiology accounting for the hemorrhage (angiography was performed in normotensive patients $\leq 45$ years of age and in patients with recurrent hemorrhages to exclude the vessel malformation or aneurysm).

\section{Data Collection}

The medical records of subjects enrolled were studied retrospectively to collect data. The following characteristics of patients were recorded: gender, age, hospital stay, history of hypertension, location of hematoma (including ventricular extension), hematoma volume [estimated by a validated practical rule, $A B C / 2$, as described in published literature (10)], Glasgow Coma Scale (GCS) score on admission, onset time, operation time. Re-bleeding, death and complications (i.e. infections associated with aspiration including intracranial infection and scalp infections, and pneumoencephalos) were also recorded.

Telephone questionnaire surveys were conducted on patients or their relatives, only if when patients can't understand or accurately state. Glasgow Outcome Scale (GOS) and BarthelIndex $(\mathrm{BI})$ were adopted to evaluate the long-term outcomes of patients. According to the scores of GOS, outcomes of patients were dichotomized into favorable $(G O S>3)$ and unfavorable $(\mathrm{GOS} \leq 3)$. Follow-up information of all the patients was obtained by a investigator who was not involved in the data collection of medical records.

\section{INTERVENTION}

\section{Traditional Way of Aspiration}

The traditional procedure of aspiration was as follows: preoperative preparation, locating hematoma, surgical manipulation and postoperative management, which were performed in according with the Operation Manual provided by the Bureau of Cerebrovascular Disease Prevention and Control, Ministry of Health of China. The YL-1 type of puncture needle used for intracranial hematoma was consists of metal drill bit, fixed hoop, canula of three-way joint, plastic blunt stylet, disrupting hematoma needle, non-porous blocks, and gasket (as shown in Figure $1 \mathrm{~A}-\mathrm{H}$ ). All the operations were performed under local anesthesia and intravenous sedation unless the patient was already intubated for medical or neurological indications independent of the procedure.

The surgical manipulation procedure was consisted of three steps: location, aspiration and drainage of clots. The initial localization of the hematoma was performed with the aid of CT-graph scanned after onset. In brief, after the largest layer of the hematoma and the aspiration target (usually the center of clot) were determined, the lines of " $a$ ", " $b$ " and " $c$ " from the target to the front coronal plane, the lateral plane of ipsilateral hematoma, and the baseline of CT-graph (usually OM-line) were measured and calculated respectively. Then the baseline was drawn on the scalp of patient. Two lines paralleled to baseline and front coronal plane with lines of " $a$ " and "c" cross at the point of aspiration (as shown in Figure 2A). After that, a metal marker was affixed to line of the aspiration point. Then CT scan was performed again, and the aspiration point was accurately confirmed and marked once again under real-time imaging aid (as shown in Figure 2B). The line of "b" represented the depth of puncture.

The details of aspiration and drainage of clots was shown in Figure $2 C$. Briefly, the puncture needle was fixed to chargehand bit (rotation speed $\leq 700 \mathrm{r} / \mathrm{min}$ ), and then cerebral dura mater was penetrated. After pulling out the metal bit, a plastic 


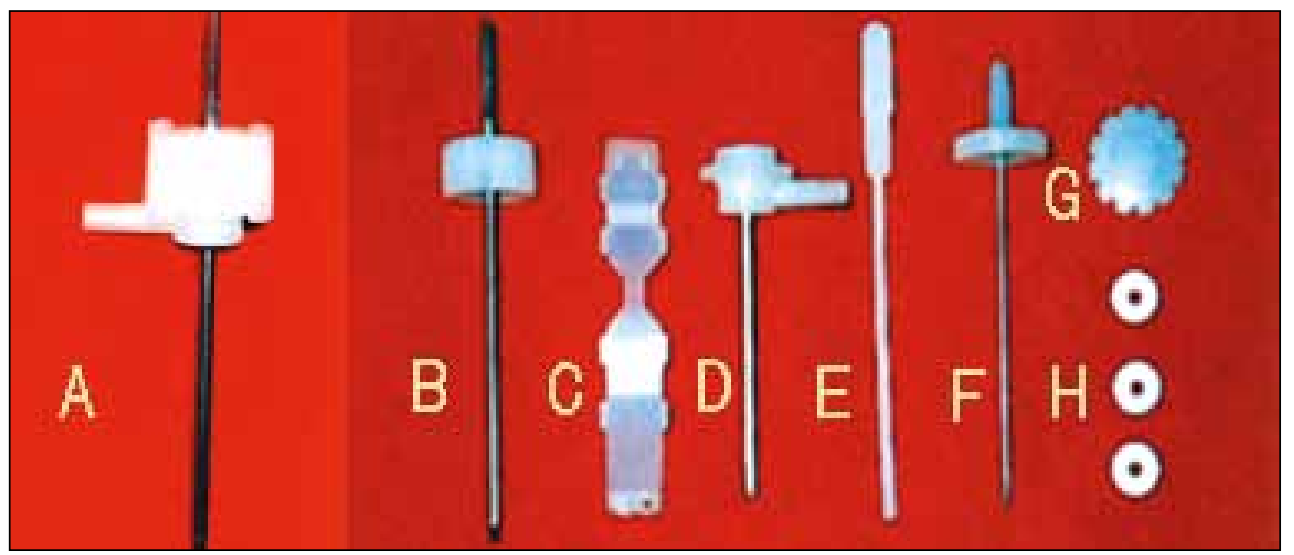

Figure 1: Components of puncture needle.

YL-1 type of puncture needle for intracranial clots $(\mathbf{A})$ is consisted of metal drill bit (B), fixed hoop (C), canula of three-way joint (D), plastic blunt stylet (E), needle to disrupt hematoma (F), nonporous blocks (G), and gasket (H). The material of metal drill bit is $1 \mathrm{Cr} 18 \mathrm{Ni9Ti}$, the canula is $0 \mathrm{Cr} 18 \mathrm{Ni}$, and the remaining parts are polyethylene.
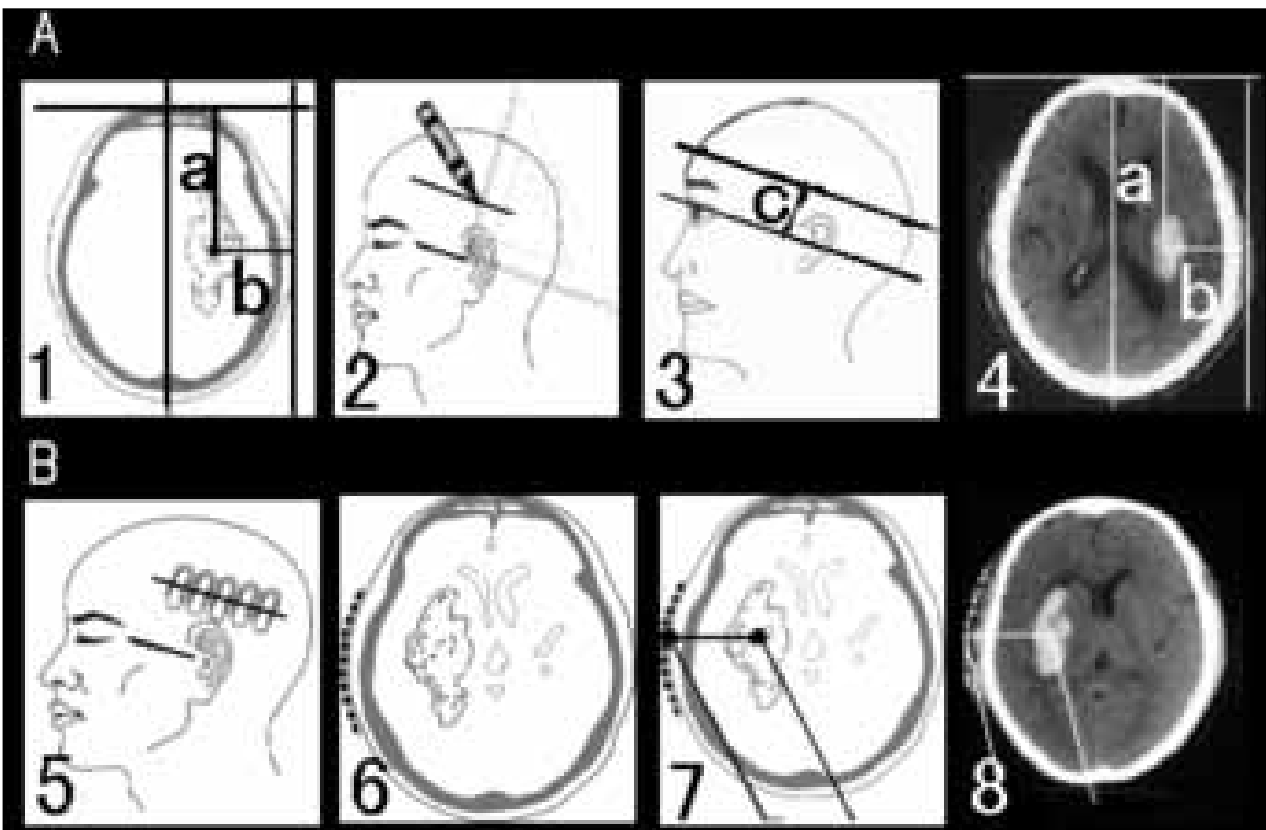

Figure 2: Aspiration

manipulations.

A) Location of hematoma by CT-graph. "a" and "b" represent the perpendicular distances from the aspiration target to the front coronal plane and lateral plane of ipsilateral hematoma (Graph 1 and 4). "c" represents the distance from the target to the baseline of CT-graph (Graph 3). B) Accurate location of hematoma under CT-scanning.

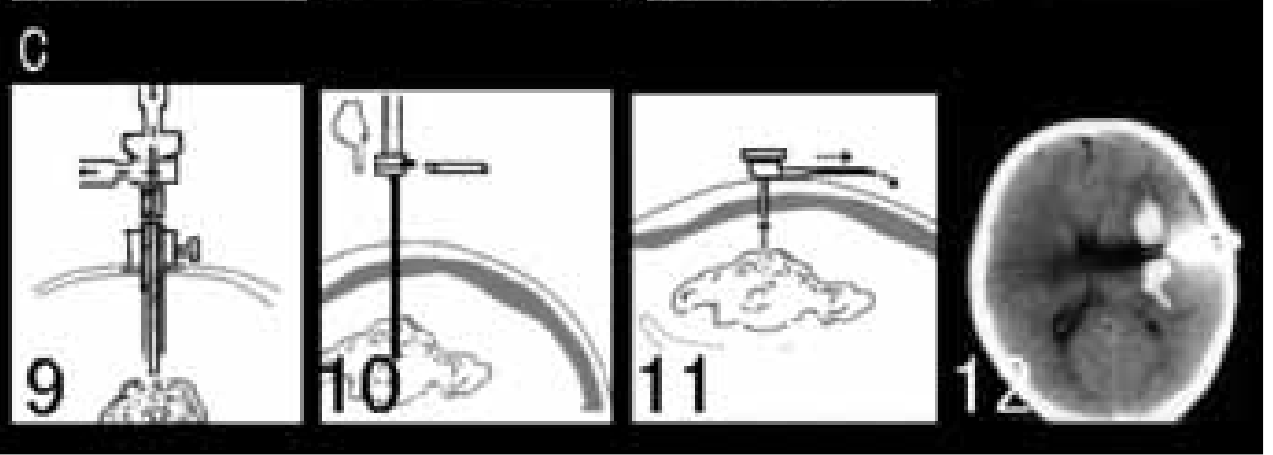
The metal marker of paper clip is fixed to the line of the aspiration point (Graph 5). C) The procedure of aspiration operation. The procedure includes sucking and liquefying the hematoma (Graph 9), flushing and disrupting clot with high pressure (Graph 10), and continual fibrinolysis and continual draining (Graph 11 and 12).

blunt stylet was inserted into the canula and pushed to the pre-calculated position (depth of " $b$ " as shown in Figure 2A). The liquid clot was sucked out through lateral tube of the canula by a $5-\mathrm{mL}$ syringe. Then a needle (used to disrupt hematoma) was inserted into the canula, and solid or semisolid hematoma was mechanically disrupted and flushed using physiological saline. And then, Urokinase 20000 IU (Urokinase was permitted to use clinically as a thrombolytic agent in treatment of the intracranial hematoma in China Guideline for
Cerebrovascular Disease Prevention and Treatment.) in 2-mL preservative-free saline was injected into the clot through the canula and maintained for 2 hours. Continual thrombolysis was repeated 2-4 times per day, and continuous draining was maintained until the clot was cleared (not more than 7 days).

\section{Modified Way of Aspiration (Gradient Aspiration)}

Compared with the traditional way of aspiration, modified way of aspiration paid emphasis on individualized treatment. The 
protocol was based on our long term practice of aspiration. (a) The amount of clot aspirated in the first operation was determined by onset time. Within 6 hours of hemorrhage onset, the amount of clot aspirated at the first aspiration should be not more than $20 \%$ of the amount of pre-operation. If onset time was $>6$ hours, the amount of clot aspirated at the first aspiration should be $20 \%-50 \%$ of the amount of preoperation (hematoma volume $<50 \mathrm{~cm}^{3}$, no enlarging, round or oval shape, well-distributed density and no extending to ventricle), or $<20 \%$ of the amount of pre-operation (situations were contrary to the aforementioned or there were suspected underlying structural etiology for the clot). (b) The operation of aspiration should be conducted prudently and slowly, and the negative pressure of suction should not be more than $1 \mathrm{~mL}$ (about $9.3 \times 10^{4} \mathrm{~Pa}$ ). The technique of disrupting and flushing clots was abandoned. (c) Continual thrombolysis (Urokinase $20000 \mathrm{IU}$ in 2-mL physiological saline) and continuous draining were strictly controlled (not more than one time per day). Because there was lacking of evidence that fibrinolytics did no harmful to the brain (2).

\section{Other Routine Medical Therapy}

Medical therapy was administered under the guidelines of China, including maintenance of normovolemic hydration, early mobilization, and physiotherapy. Systolic blood pressure and diastolic blood pressure were maintained at about 120$180 \mathrm{mmHg}$ and $60-105 \mathrm{mmHg}$ respectively. Enteric feeding began at the first day if tolerated. Osmotic diuretics were administered when clinical manifestations indicated high intracranial pressure. Complications were prevented and treated.

\section{Statistical Analysis}

The clinical outcomes of patients treated with different ways of aspiration were compared by means of unpaired t-test and Chi-square test. Statistical significance was set at $\mathrm{P}<0.05$ and was always measured two-tailed.

\section{RESULTS}

One hundred and fifty-nine patients with a median age of 55 years (ranged from 33 to 86 years) were enrolled in this study. Clinical data during hospital stay were summarized in table 1 . Sixty-six patients (median age 56 years, ranged 3976 years) received aspiration operation with traditional way (group A), and 93 patients (median age 55 years, ranged 3386 years) received aspiration operation with modified way (group B). There was no significant difference between the two groups with regard to the clinical data such as male sex, age, length of hospital stay, history of hypertension, location of clot (including clots located at right side, basal ganglia or thalamus, deep lobar and cases extended to ventricle), hematoma volume, GCS at pre-operation, onset time and operation time $(\mathrm{P}>0.05)$ (Table I).

\section{Reduction of Clot Volume in the First Operation}

Reduction of clot volume in the first operation in 159 patients was $(17.1 \pm 8.4) \mathrm{mL}[(32.2 \pm 15.5) \%]$ (Table II). The number in group A was $(22.2 \pm 10.1) \mathrm{mL}$ [ $(40.3 \pm 16.5) \%]$, which was significantly higher than that in group $B(13.6 \pm 4.1) \mathrm{mL}$ [ (26.5 \pm 11.8$) \%](P<0.001)$ (Table II).

\section{Rate of Mortality and Re-bleeding}

As shown in Table II, 25 out of 159 patients (15.7\%) died during hospital stay. Mortality of group A $(22.7 \%$, 15 out of $66)$ was significantly higher than that of group $B(10.8 \%, 10$ out of 93) $(P<0.05)$.

Re-bleeding during hospital stay occurred in 7 (4.4\%, 7 out of 159) patients, and 6 patients $(9.1 \%, 6$ out of 66$)$ occurred in group A compared with 1 patient (1.1\%, 1 out of 93 ) in group $B(P<0.05)$ (Table II).

\section{Complications}

Procedure-related complications were observed in 46 out of 159 patients $(29.0 \%)$ during hospital stay (Table II). Infection was observed in 11 of 66 patients (16.7\%) in group $A$ and 9 of 93 patients $(9.7 \%)$ in group $B(P>0.05)$, and 20 of 159 patients (12.6\%). Infection was occurred mostly to scalp and scarcely to intracranial tissue. The total rate of pneumoencephalos during hospital stay was $16.4 \%(26 / 159)$, and that in group A and group $B$ was $21.2 \%(14 / 66)$ and $12.9 \%$ (12/93) respectively $(P>0.05)$. In most situations, there was only a small air bubble (usually not more than $1 \mathrm{ml}$ ) on the border of clot, which disappeared in several days without any special management.

\section{Follow-up}

The data of follow-up were summarized in Table III. In the 134 discharged patients, 19 (14.2\%) were lost. In group A 11 out of $51(21.6 \%)$ were lost and in group B 8 out of 83 (9.6\%) were lost $(P>0.05)$. In the 115 patients followed up, the mortality rate was $16.5 \%$ (19 out of 115 ). In group $A$ the mortality rate was $17.5 \%$ (7 out of 40 ) and in group $B$ the rate was $16.0 \%$ (12 out of 75$)(P>0.05)$. The mean follow-up period of total 115 patients was (172.7 \pm 119.1$)$ weeks (ranged 23.7-398.1 weeks). In group $A$ the mean follow-up period was (321.4 \pm 53.8 ) weeks (ranged 200.0-398.1 weeks) and in group $B$ the number was (93.4 \pm 44.7$)$ weeks (ranged 23.7-178.3 weeks) $(P<0.001)$.

57 out of 115 patients (49.6\%) achieved a favorable functional outcome score (GOS>3). In group A 17 out of 40 patients (42.5\%) achieved a favorable functional outcome score $(\mathrm{GOS}>3)$ and 40 out of $75(52.6 \%)$ in group $B(P=0.329)$. Mean $\mathrm{BI}$ at a long-term follow-up period in total 115 patients was (76.0 \pm 23.2$)$. In group B the mean BI was (79.5 \pm 23.2$)$, which was significantly higher than that of group $A(69.2 \pm 23.9)$ $(\mathrm{P}=0.044)$.

\section{DISCUSSION}

It was still controversial for the effect of stereotactic aspiration of ICH $(1,6,12,22)$. A famous trial named SICHPA (Stereotactic Treatment of Intracerebral Hematoma by means of a Plasminogen Activator) suggested that stereotactic aspiration was an effective operation to remove hematoma and improved the prognosis of patients (22). Moreover, many studies indicated that stereotactic aspiration was not only effective in removing the clots, but also help to lower the 
Table I: Baseline Characteristics

\begin{tabular}{|c|c|c|c|}
\hline & Group A (n=66) & Group B (n=93) & $\mathbf{P}$ \\
\hline Male sex & 48 (72.7\%) & $66(71.0 \%)$ & 0.859 \\
\hline $\begin{array}{c}\text { Age (years) } \\
\text { Median } \\
\text { Range }\end{array}$ & $\begin{array}{c}58.2 \pm 10.3 \\
56 \\
39-76\end{array}$ & $\begin{array}{c}55.2 \pm 10.2 \\
55 \\
33-86\end{array}$ & 0.069 \\
\hline $\begin{array}{l}\text { Hospital stay (days) } \\
\text { Median } \\
\text { Range }\end{array}$ & $\begin{array}{c}17.7 \pm 15.1 \\
15 \\
1-61\end{array}$ & $\begin{array}{c}18.5 \pm 13.8 \\
16 \\
1-67\end{array}$ & 0.727 \\
\hline History of hypertension & $48(72.7 \%)$ & $66(71.0 \%)$ & 0.859 \\
\hline $\begin{array}{l}\text { Location of ICH } \\
\text { Right side } \\
\text { Basal ganglia or thalamus } \\
\text { Deep lobar } \\
\text { Ventricular extension }\end{array}$ & $\begin{array}{l}38(57.6 \%) \\
49(74.2 \%) \\
17(25.8 \%) \\
29(43.9 \%)\end{array}$ & $\begin{array}{c}43(46.2 \%) \\
61(65.6 \%) \\
32(34.4 \%) \\
39(41.9)\end{array}$ & $\begin{array}{l}0.198 \\
0.297 \\
0.297 \\
0.871\end{array}$ \\
\hline $\begin{array}{l}\text { Volume of ICH }\left(\mathrm{cm}^{3}\right) \\
\text { Median } \\
\text { Range }\end{array}$ & $\begin{array}{c}58.7 \pm 24.5 \\
51.8 \\
30.0-135.0\end{array}$ & $\begin{array}{l}57.9 \pm 23.5 \\
50.0 \\
30.0-120.0\end{array}$ & 0.827 \\
\hline $\begin{array}{l}\text { GCS pre-operation } \\
\text { Median } \\
\text { Range }\end{array}$ & $\begin{array}{c}8.0 \pm 4.3 \\
5 \\
3-15\end{array}$ & $\begin{array}{c}8.7 \pm 4.5 \\
9 \\
3-15\end{array}$ & 0.308 \\
\hline $\begin{array}{l}\text { Onset time }(\mathrm{h}) \\
\text { Median } \\
\text { Range }\end{array}$ & $\begin{array}{c}11.1 \pm 11.1 \\
6.4 \\
1.0-48.0\end{array}$ & $\begin{array}{c}13.6 \pm 12.8 \\
8.0 \\
2.0-52.0\end{array}$ & 0.203 \\
\hline $\begin{array}{l}\text { Operation time }(\mathrm{h}) \\
\text { Median } \\
\text { Range }\end{array}$ & $\begin{array}{c}20.7 \pm 13.6 \\
17.8 \\
3.0-64.0\end{array}$ & $\begin{array}{c}24.5 \pm 14.3 \\
23.0 \\
3.0-65.0\end{array}$ & 0.085 \\
\hline
\end{tabular}

Table II: Clinical Data

\begin{tabular}{|c|c|c|c|}
\hline & Group A $(n=66)$ & Group B (n=93) & $\mathbf{P}$ \\
\hline $\begin{array}{l}\text { Volume of clot reduction }\left(\mathrm{cm}^{3}\right) \\
\text { Median } \\
\text { Range }\end{array}$ & $\begin{array}{l}22.2 \pm 10.1 \\
20.0 \\
5.0-55.0\end{array}$ & $\begin{array}{l}13.6 \pm 4.1 \\
15.0 \\
3.0-22.0\end{array}$ & $<0.001$ \\
\hline $\begin{array}{l}\text { Rate of clot reduction (\%) } \\
\text { Median } \\
\text { Range }\end{array}$ & $\begin{array}{l}40.3 \pm 16.5 \\
40.2 \\
9.9-83.3\end{array}$ & $\begin{array}{l}26.5 \pm 11.8 \\
19.8 \\
2.7-50.0\end{array}$ & $<0.001$ \\
\hline Rate of re-bleeding & $6(9.1 \%)$ & $1(1.1 \%)$ & 0.015 \\
\hline Mortality of in-hospital & $15(22.7 \%)$ & $10(10.8 \%)$ & 0.048 \\
\hline Rate of infection & $11(16.7 \%)$ & $9(9.7 \%)$ & 0.228 \\
\hline Rate of pneumoencephalos & $14(21.2 \%)$ & $12(12.9 \%)$ & 0.194 \\
\hline
\end{tabular}

rate of mortality and improve the long-term quality of life $(1,5,7,9,24)$. However, many researchers hold the opposite view. Some trials like STICH (International Surgical Trial in Intracerebral Haemorrhage) suggested that patients with spontaneous supratentorial $\mathrm{ICH}$ in neurosurgical units show no overall benefit from early surgery when compared with initial conservative treatment (12). Many reasons accounted for this controversy, one of which was that some operational details of aspiration were yet to be improved. Compared with craniotomy, the technique of less invasive clot aspiration means the less tissue trauma. If the procedure of operation were more refined and careful, the prognosis of patients 
would be more favorable (29). In light of this, we conducted this research.

In order to release the mass effect and reduce the secondary brain damage as soon as possible, the technique of traditional aspiration generalized by Ministry of Health of China attached great importance to the removal of clots. However, according to the experiences of our clinical practice we presumed that too rapidly removal of clots and too frequently use of fibrinolysis would increase the probability of re-bleeding (30) and infection. From 2004, some modifications were made to the traditional way of aspiration in our team. Clearing clots in a short time was no longer the emphasis of the modified way of aspiration. In fact, the volume of clots sucked in the first operation was significantly lower in group $A$ than in group B. In addition, there was still a good effect of removing clot using continuous drainage and continual fibrinolysis, as shown in Figure 3A-G.

Our data showed that the rate of post-operation rehemorrhage during hospital stay was $4.4 \%$, which was similar to most of the published literatures (2). Rebleeding rate in group B $(1.1 \%)$ was significantly lower than that in group $A(9.1 \%)$. It suggested that sucking too big volume of clots in a short time

Table III: Results of Follow-up

\begin{tabular}{|c|c|c|c|}
\hline & Group A & Group B & $\mathbf{P}$ \\
\hline Rate of follow-up loss & $11 / 51(21.6 \%)$ & $8 / 83(9.6 \%)$ & 0.074 \\
\hline $\begin{array}{l}\text { Time period (weeks) } \\
\text { Median } \\
\text { Range }\end{array}$ & $\begin{array}{c}321.4 \pm 53.8(n=40) \\
315.6 \\
200.0-398.1\end{array}$ & $\begin{array}{c}93.4 \pm 44.7(n=75) \\
88.0 \\
23.7-178.3\end{array}$ & 0.001 \\
\hline Mortality of follow-up & $7 / 40$ (17.5\%) & $12 / 75(16.0 \%)$ & 1.000 \\
\hline Rate of GOS > 3 & $17 / 40(42.5 \%)$ & $40 / 75$ (52.6\%) & 0.329 \\
\hline $\begin{array}{l}\text { Barthel-Index } \\
\text { Median } \\
\text { Range }\end{array}$ & $\begin{array}{c}69.2 \pm 23.9(n=33) \\
75 \\
15-100\end{array}$ & $\begin{array}{c}79.5 \pm 23.2(n=64) \\
85 \\
5-100\end{array}$ & 0.044 \\
\hline
\end{tabular}
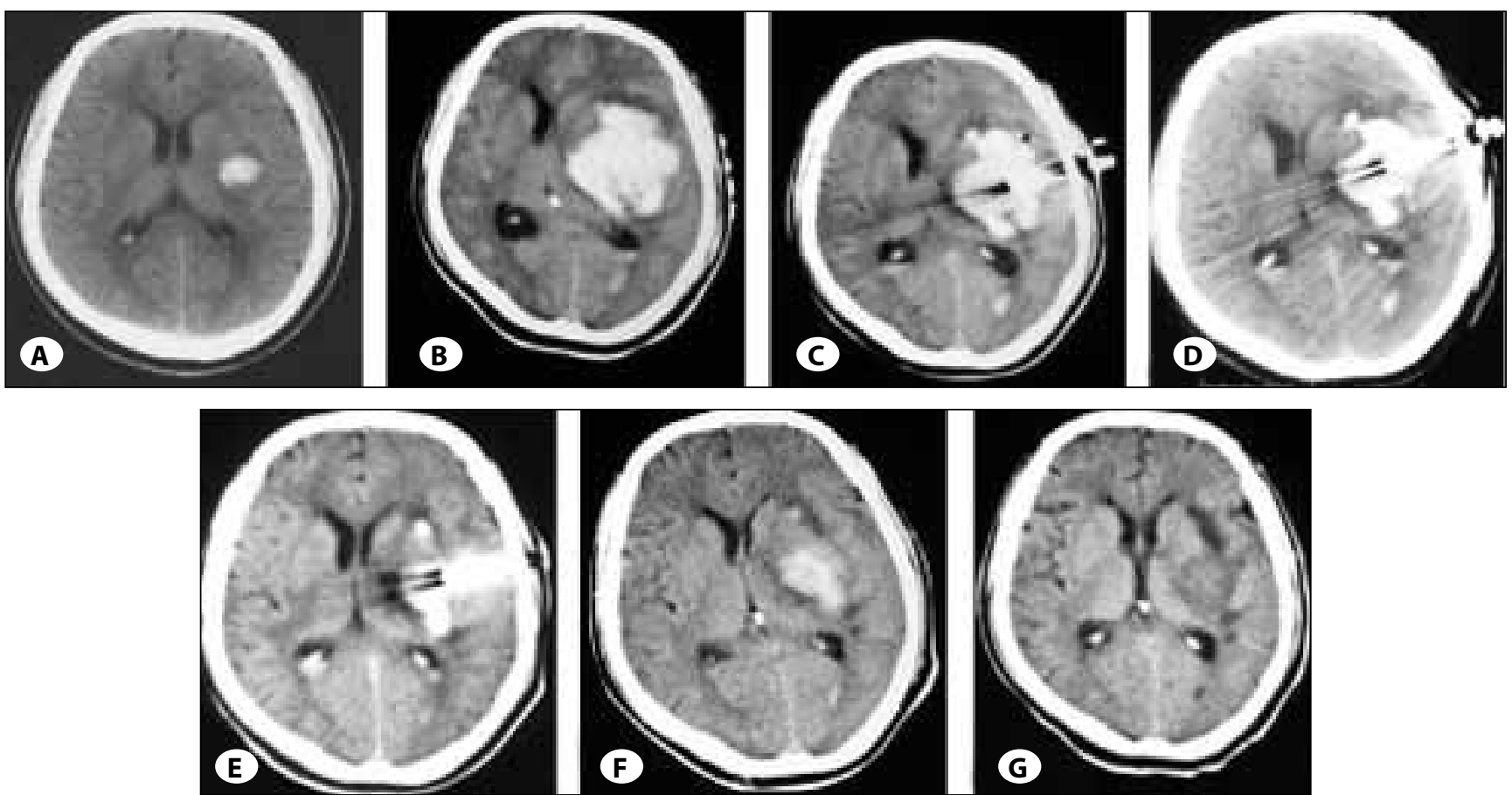

Figure 3: CT scans of a patient treated by aspiration. A-B) Preoperative CT scan of a 47-year-old male patient with a left basal ganglia hematoma (" $\mathrm{A}$ ": post-onset 2 hours; "B": post-onset 12 hours and the volume of hematoma was $108 \mathrm{~cm}^{3}$ ). The patient was treated with the technique of modified aspiration and $10-\mathrm{mL}$ of blood was sucked in the first operation (C). And then the patient received thrombolysis per day after operation. On the 5th day the puncture needle was removed. The hematoma decreased gradually (D) on the third day post-operation; (E) on the 5th day post-operation; (F) on the 14th day post-operation; (G) on the 26th day postoperation). GOS and BI (the follow-up time was 122 weeks) was 4 and 90 respectively. 
would lead to re-open the ruptured artery for the sharply decline of the intracranial pressure. Re-bleeding was one of the most serious complications of $\mathrm{ICH}$ and the decline of rebleeding rate may partly account for the significant decrease of mortality in group B (10.8\%), compared with group A (22.7\%). Though the volumes of clots in our study (median $50.6 \mathrm{~cm}^{3}$ ) were relatively larger than that of many other studies $(8,14,23)$, the total rate of mortality was low $(15.7 \%)$.

Data from many researches suggested the procedure-related complications (i.e. infections and pneumoencephalos) should not be ignored $(19,23,24)$. In our study, though there were no statistically significant differences, the rate of infections and pneumoencephalos were lower in group B than that in group A. The high sucking pressure and the breaking down of the closed environment of aspiration system during the operational procedure were the probable reasons for pneumoencephalos.

In our research, $49.6 \%$ of the patients got a favorable functional outcome (GOS>3) and the mean Bl in the long-term follow-up period was (76.0 \pm 23.2$)$, which were both higher than that in previously published data $(6,13)$. Moreover, the mean $\mathrm{BI}$ of group $B$ was significantly higher than that in group $A(P=0.044)$. Many data showed that well removing clots helped to reduce the mortality in the early stage of onset, but whether helped to improve the long-term quality of life was a controversy ( 2 , $19,20,23,28)$. Data from our study suggested that patients received modified way of aspiration got a favorable outcome.

In conclusion, the present study showed that aspiration with metal puncture needle was an effective way to remove clots. Modifying details of aspiration operation improved the prognosis of the $\mathrm{ICH}$ patients. To get more compelling data, a prospective clinical trial (ClinicalTrials.gov Identifier: NCT00752024) are in progress.

\section{REFERENCES}

1. Barrett RJ, Hussain R, Coplin WM, Berry S, Keyl PM, Hanley DF, Johnson RR, Carhuapoma JR: Frameless stereotactic aspiration and thrombolysis of spontaneous intracerebral hemorrhage. Neurocrit Care 3: 237-245, 2005

2. Broderick J, Connolly S, Feldmann E, Hanley D, Kase C, Krieger D, Mayberg M, Morgenstern L, Ogilvy CS, Vespa P, Zuccarello $M$ : Guidelines for the management of spontaneous intracerebral hemorrhage in adults: 2007 update: A guideline from the American Heart Association/American Stroke Association Stroke Council, High Blood Pressure Research Council, and the Quality of Care and Outcomes in Research Interdisciplinary Working Group. Circulation 116: e391-413, 2007

3. Broderick JP, Brott T, Tomsick T, Miller R, Huster G: Intracerebral hemorrhage more than twice as common as subarachnoid hemorrhage. J Neurosurg 78: 188-191, 1993

4. Carhuapoma JR, Barrett RJ, Keyl PM, Hanley DF, Johnson RR: Stereotactic aspiration-thrombolysis of intracerebral hemorrhage and its impact on perihematoma brain edema. Neurocrit Care 8: 322-329, 2008
5. Chen $\mathrm{CH}$, Lee HT, Shen CC, Sun MH: Aspiration of hypertensive intracerebral hematoma with frameless and fiducial-free navigation system: Technical note and preliminary result. Stereotact Funct Neurosurg 86: 288-291, 2008

6. Deinsberger W, Lang C, Hornig C, Boeker DK: Stereotactic aspiration and fibrinolysis of spontaneous supratentorial intracerebral hematomas versus conservative treatment: A matched-pair study. Zentralbl Neurochir 64: 145-150, 2003

7. Hondo H, Uno M, Sasaki K, Ebisudani D, Shichijo F, Toth Z, Matsumoto K: Computed tomography controlled aspiration surgery for hypertensive intracerebral hemorrhage. Experience of more than 400 cases. Stereotact Funct Neurosurg 54-55: 432-437, 1990

8. Kandel El, Peresedov VV: Stereotaxic evacuation of spontaneous intracerebral hematomas. J Neurosurg 62: 206-213, 1985

9. Kim IS, Son BC, Lee SW, Sung JH, Hong JT: Comparison of frame-based and frameless stereotactic hematoma puncture and subsequent fibrinolytic therapy for the treatment of supratentorial deep seated spontaneous intracerebral hemorrhage. Minim Invasive Neurosurg 50: 86-90, 2007

10. Kothari RU, Brott T, Broderick JP, Barsan WG, Sauerbeck LR, Zuccarello M, Khoury J: The ABCs of measuring intracerebral hemorrhage volumes. Stroke 27: 1304-1305, 1996

11. Little KM, Alexander MJ: Medical versus surgical therapy for spontaneous intracranial hemorrhage. Neurosurg Clin N Am 13: 339-347, 2002

12. Mendelow AD, Gregson BA, Fernandes HM, Murray GD, Teasdale GM, Hope DT, Karimi A, Shaw MD, Barer DH: Early surgery versus initial conservative treatment in patients with spontaneous supratentorial intracerebral haematomas in the International Surgical Trial in Intracerebral Haemorrhage (STICH): A randomised trial. Lancet 365: 387-397, 2005

13. Morgenstern LB, Frankowski RF, Shedden P, Pasteur W, Grotta JC: Surgical treatment for intracerebral hemorrhage (STICH): a single-center, randomized clinical trial. Neurology 51: 13591363, 1998

14. Muiz AJ, Abdullah J, Naing NN, Ghazaime G, Ariff AR: Spontaneous intracerebral hemorrhage in northeast Malaysian patients: A four-year study. Neuroepidemiology 22: 184-195, 2003

15. Naval NS, Nyquist $P$, Carhuapoma JR: ICH aspiration and thrombolysis. J Neurol Sci 261: 80-83, 2007

16. Nehls DG, Mendelow AD, Graham DI, Sinar EJ, Teasdale GM: Experimental intracerebral hemorrhage: Progression of hemodynamic changes after production of a spontaneous mass lesion. Neurosurgery 23: 439-444, 1988

17. Nehls DG, Mendelow DA, Graham DI, Teasdale GM: Experimental intracerebral hemorrhage: Early removal of a spontaneous mass lesion improves late outcome. Neurosurgery 27: 674-682; discussion 682, 1990

18. Paillas JE, Alliez B: Surgical treatment of spontaneous intracerebral hemorrhage. Immediate and long-term results in 250 cases. J Neurosurg 39: 145-151, 1973 
19. Rohde V, Graf G, Hassler W: Complications of burr-hole craniostomy and closed-system drainage for chronic subdural hematomas: A retrospective analysis of 376 patients. Neurosurg Rev 25: 89-94, 2002

20. Schaller C, Rohde V, Hassler W: Local thrombolytic treatment of spontaneous intracerebral hemorrhage with plasminogen activator (rt-PA). Indications and limits. Nervenarzt 66: 792, 1995

21. Shi Y, Li Z, Zhang S, Xie M, Meng X, Xu J, Liu N, Tang Z: Establishing a model of supratentorial hemorrhage in the piglet. Tohoku J Exp Med 220: 33-40,

22. Teernstra OP, Evers SM, Lodder J, Leffers $P$, Franke $C L$, Blaauw $\mathrm{G}$ : Stereotactic treatment of intracerebral hematoma by means of a plasminogen activator: A multicenter randomized controlled trial (SICHPA). Stroke 34: 968-974, 2003

23. Thiex R, Rohde V, Rohde I, Mayfrank L, Zeki Z, Thron A, Gilsbach JM, Uhl E: Frame-based and frameless stereotactic hematoma puncture and subsequent fibrinolytic therapy for the treatment of spontaneous intracerebral hemorrhage. J Neurol 251: 1443-1450, 2004

24. Vespa P, McArthur D, Miller C, O'Phelan K, Frazee J, Kidwell C, Saver J, Starkman S, Martin N: Frameless stereotactic aspiration and thrombolysis of deep intracerebral hemorrhage is associated with reduction of hemorrhage volume and neurological improvement. Neurocrit Care 2: 274-281, 2005
25. Wagner KR, Xi G, Hua Y, Zuccarello M, de Courten-Myers GM, Broderick JP, Brott TG: Ultra-early clot aspiration after lysis with tissue plasminogen activator in a porcine model of intracerebral hemorrhage: Edema reduction and blood-brain barrier protection. J Neurosurg 90: 491-498, 1999

26. Wang WZ, Jiang B, Liu HM, Li D, Lu CZ, Zhao YD, Sander JW: Minimally invasive craniopuncture therapy vs. conservative treatment for spontaneous intracerebral hemorrhage: Results from a randomized clinical trial in China. Int J Stroke 4: 11-16, 2009

27. Xu F, Tang Z, Luo X, Kang H, Hu Q, Wang W, Zhu S: No evidence of preoperative hematoma growth representing an increased postoperative rebleeding risk for minimally invasive aspiration and thrombolysis of $\mathrm{ICH}$. Br J Neurosurg 24: 268274,

28. Zhao JZ, Zhou DB, Zhou LF, Wang RZ, Wang DJ, Wang S, Yuan G, Kang S, Zhao YL, Ji N, Ye X: The efficacy of three different approaches in treatment of hypertensive intracerebral hemorrhage: A multi-center single-blind study of 2464 patients. Zhonghua Yi Xue Za Zhi 85: 2238-2242, 2005

29. Wang Y, Lei T, Wang Z: Minimally invasive neuronavigatorguided microsurgery and photodynamic therapy for gliomas. J Huazhong Univ Sci Technolog Med Sci 29: 395-398, 2009

30. Yang R, Zhang X, Wei W, Hong $M$, Yang $Y$, Hu Y: Relationship between acquired deficiency of vitamin $\mathrm{K}$-dependent clotting factors and hemorrhage. J Huazhong Univ Sci Technolog Med Sci 30: 312-331, 2010 